Doi: HTTPS://DOI.ORG/10.23910/2/2020.0351

\title{
Melia dubia and its Importance: A Review
}

\author{
Manika Goswami ${ }^{1}$, Shikha Bhagta ${ }^{2}$ and Dushyant Sharma ${ }^{3 *}$
}

${ }^{1}$ Dept. of Fruit Science, College of Horticulture and Forestry, Neri, Hamirpur, Himachal Pradesh (177 001), India

${ }^{2}$ Dept. of Tree Improvement and Genetic Resources, Dr. Y. S. Parmar University of Horticulture and Forestry, Nauni, Solan, Himachal Pradesh (173 230), India

${ }^{3}$ Dept. of Tree Improvement and Genetic Resources, College of Horticulture and Forestry, Neri, Hamirpur, Himachal Pradesh

(177 001), India

\section{Corresponding Author}

Dushyant Sharma

e-mail: sharmadus@gmail.com

\author{
Article History \\ Article ID: IJEP0351 \\ Received in $27^{\text {th }}$ December, 2019 \\ Received in revised form $11^{\text {th }}$ January, 2020 \\ Accepted in final form 19 ${ }^{\text {th }}$ January, 2020
}

\section{Abstract}

Melia dubia popularly known as Malabar Neem is a promising multipurpose tree highly suitable for farm forestry and agro forestry for generating higher income per unit area. Melia dubia is one of the fastest growing trees in the world and considered as a money spinning tree of short rotation due to its high demand in pulpwood, plywood and timber industries. It is a good fuel and fodder yielding tree. In addition to this, Melia dubia also has extensive medicinal, pharmacological, ethnomedicinal and conventional properties and uses. The current article reviews literature on importance of Melia dubia for timber industry and medicinal value.

Keywords: Antioxidant, antimicrobial, antifeedent, Melia dubia, timber

\section{Introduction}

The less forest area coupled with the low productivity of Indian forest has ushered in a total mismatch between the demand and supply of both domestic and industrial wood requirement besides creating environmental disequilibrium (Parthiban et al., 2011). The current supply of raw materials for industries like pulpwood, plywood, and furniture and biomass energy in the country is far behind the demand. Not only is the forest wealth of the country is poor but its productivity in terms of MAl is also one of the lowest. The MAI of Indian Forest is a meager of $0.5-0.7 \mathrm{~m}^{3} \mathrm{ha}^{-1}$ compared to the global average of $2.1 \mathrm{~m}^{3} \mathrm{ha}^{-1}$ (Srivastava, 2005). India is likely to face severe shortage of supply of timber to meet its requirement from both domestic and international front. Global demand for wood is increasing at an annual rate of $1.7 \%$ (South, 1999). It is estimated that the demand for timber is likely to grow from 58 million cubic meters in 2005 to 153 million cubic meters in 2020 (Saravanan et al., 2014). At the same time, planted forest resources are insufficient to meet current demands. The scope for expansion of forested areas is limited (Gregory et al., 2002). This trend creates economic pressure that encourages the commercial exploitation of natural forests unless supply can be increased through the establishment of high yielding plantations. The use of fast growing, elite trees enable early harvest and so it helps to improve yield. However, considering the acute shortage of suitable raw material, the industries have to establish plantation of suitable species to achieve maximum yield within a short rotation period. Melia dubia is one such alternative species suitable for timber, plywood, pulpwood and fuel wood. More than $80 \%$ of the world's population presently uses herbal medicines for their primary health care as alternative system of medicine (Valentina et al., 2013). Demand for herbal drug is increasing throughout the world due to growing recognition of natural plant based products, being non toxic, having no side effects, easily available at affordable price (Kalia, 2018). Melia dubia tree in addition to use in wood industry have many potential medicinal properties. In addition to the commercial importance, this helps in preventing temperature rise and checking gas emission into the atmosphere as the trees are naturally endowed to absorb maximum $\mathrm{CO}_{2}$. Due to high value in timber industry, environment amelioration and potential medicinal properties, Melia dubia has been selected in present investigation.

\section{Habit and Habitat}

It is an indigenous species of south-east Asia and Australia belonging to family Meliaceae. In India, it is naturally found at an altitude of 600-1,800 m, especially in the Sikkim Himalayas, 
northern Bengal, Assam, Khasi hills, hilly regions of Odisha, Deccan Plateau and the Western Ghats (Gamble, 1992). Due to its wider adaptability, it can be planted successfully in most of parts of India (Shah et al., 2016). The trees grow well in sandy loam, red and lateritic soils with an annual rainfall of $800 \mathrm{~mm}$ and above. Temperature ranges between minimum of $0-15^{\circ} \mathrm{C}$ and maximum of $30-43^{\circ} \mathrm{C}$. It is found to grow normally in areas with heavy rainfall of $1000 \mathrm{~mm}$ and relative humidity of $50-90 \%$. The tree is deciduous to semievergreen in nature, which grows up to $25 \mathrm{~m}$ tall with wide spreading branches of handsome foliage. Bark is dark brown, fibrous which peels off in long strips of rectangular shape. The young branches are scurcy-tomentose and branchlets are terete, glabrous when mature. Found growing in the deciduous forests and in the country sides on wastelands. Leaves shed during December-January and the new leaves appear in February-March along with flowers. Inflorescence is an auxiliary panicle, $12-20 \mathrm{~cm}$ long; flowers are small, greenish white, honey scented, appearing in bunches with new flush of leaves. Fruit is a drupe, ovoid or ellipsoid with longitudinal ridges, pulpy and yellowish on ripening with a sweet smell. Fruit ripes in cold season (October-February), each consisting of 3-4 seeds.

\section{Importance in Timber/Wood Industry and Environment Amelioration}

The wood of this tree is used majorly in plywood industry. It has been screened as an alternate species for pulpwood (Parthiban et al., 2009). The wood is also used for packing cases, match box sticks, photo frames, pencils (Nataraj pencil company using the Melia dubia wood) mini furniture like stools, benches, wooden tables, interior decoration, window doors, wooden racks \& packing industries, musical instruments, tea powder boxes, cigar boxes, building purposes, ceiling planks agricultural implements etc. Melia dubia is a promising tree highly suitable for agro forestry or farm forestry with a life cycle of 8 to 12 years is gaining economic importance both in domestic and global markets. Melia dubia grows up to 40 feet within two years of planting and has the potential of yielding up to 40 tons of biomass on an average per acre per annum of 10 year old plantation. The minimum cultivation period is six years and it can be allowed up to 8 years for good economic value. Its commercial cultivation is getting popularized among farmers due to its characteristics such as fast growth, stem straightness without much of branches, less shade effect and for not susceptible to pest and insect attacks. The commercial importance for agro forestry plantations is increasing due to various reasons as explained above and certain tree varieties like Melia dubia is getting popularized because it fetches assured income with buyback arrangements and requires low maintenance. In addition, these trees also contribute in carbon sequestration and mitigation of climate change impacts (Thakur and Chauhan, 2008). About 400 trees can be planted in an acre which fetches Rs. 10-12 lakhs in 6-8 years time (Yadav et al., 2019). Its high calorific value makes it a viable source of feedstock for biomass power plants. In view of the ever increasing timber demand for various commercial purposes and shortage in natural resources, the importance for the fast growing Melia dubia is gaining steadily.

\section{Medicinal Value of Melia dubia}

\subsection{Antioxidant activity}

Antioxidants are the substances used by the body to protect itself from the damage caused by free radicals which causes lipid peroxidation, oxidation of DNA, proteins etc. that damage cells. Oxidative stress is one of the key factors for several diseases like cancer, diabetes, arthritis, inflammation etc (Khan et al., 2008). Hence, research has been focused on use of antioxidants with particular emphasis on naturally derived antioxidants. The phenolic compounds derived from the plants viz., tannins, flavonoids, alkaloids, terpenoids etc. are known to be potent antioxidants. Valentina et al. (2013) had reported that the solvent extracts of Melia dubia exhibited excellent antioxidant activity by Nitric oxide radical scavenging method, evidenced by lower IC50 (16.89 $\mu \mathrm{g} \mathrm{ml} l^{-1}$ ) value in the ethanolic extract. The results revealed that ethanolic fraction of Melia dubia which contains highest amount of phenolic and flavonoids compound may be contributing to antioxidant potential of the plant. The antioxidant properties of leaf and fruit extracts of Melia dubia had also been reported by many other researchers (Ahmad et al., 2008; Charde et al., 2010; Ahmad et al., 2012; Shah et al., 2016). The fruit extract of Melia dubia established a significant scope to develop a broad spectrum use in herbal medicine and as a base for the development of novel potent drugs against the oxidative stress related health disorders in human beings (Kumar and Chauha, 2019).

\subsection{Anticancer activity}

Silver nanoparticles using the plant extract of Melia dubia were synthesized and characterized by using UVvisible, XRD and SEM-EDS (Karthiravan et al., 2014). The effect of the silver nanoparticles on human breast cancer (KB) cell line has been tested. Silver nanoparticles showed remarkable cytotoxicity activity against KB cell line with evidence of high therapeutic index value. Many other researchers also reported anticancer properties of Melia dubia plant extract (Anusuya et al., 2011; Husseiny et al., 2015; Saber et al, 2018).

\subsection{Antimicrobial activity}

Melia dubia has been tested for their antimicrobial activity against ten different pathogenic microorganisms responsible for human pathologies using standard antimicrobial assays. Melia dubia leaf essential oil exhibited bacteriostatic and fungistatic activities against Pseudomonas aeruginosa, Escherichia coli, Klebsiella pneumoniae and Fusarium oxysporum and Candida albicans, respectively (Nagalakshmi et al., 2003). Netala et al. 
(2014) investigated the bio-fabrication of silver nanoparticles (AgNPs) using aqueous leaf extract of Melia dubia (ALM) and tested the antifungal activity of AgNPs against pathogenic fungi Aspergillus niger and Candida tropicalis and concluded that the bio-fabrication of AgNPs using aqueous leaf extract was robust and rapid. The AgNPs were stable and proved to be excellent antifungal agents.

Extracts of the leaves and root of Melia dubia inhibited the growth of K. pneumonia, E. coli and Staphylococcus aureus, while only the leaf extract was active against $S$. typhi and $S$. paratyphi (Chanthuru et al., 2014). The results obtained in this present study have lent scientific justification to some of the uses of this plant in ethno-medicine. Antimicrobial properties of solvent extracts of the leaves and primary fractions of the tested plants of Melia dubia was investigated following the disc diffusion method against human pathogens and petroleum ether extract of $M$. dubia was found most effective for almost all the pathogens (Malarvannan et al., 2009).

\subsection{Antidiabetic activity}

The extract of Melia dubia fruits in alcohol was found to be most effective as a hypoglycaemic agent (Susheela et al., 2008). Varying doses of ethanol extract of total fruits injected intraperitoneally into mice reduced blood glucose level, but maximum reduction of $52.14 \%$ was observed at a dose of $300 \mathrm{mg} \mathrm{kg}^{-1}$ body weight by the sixth hour. The therapeutic index value of 2.5 of the total fruit extract suggests that the extract is not only safe but an effective, natural and novel hypoglycaemic agent, as indicated from the evaluation on mice. The studied conducted by Mamun-or-Rashid et al. (2014); Nojima et al. (1998); Makheswari et al. (2012); Schwab et al. (2006) also demonstrated the importance of Melia dubia in the treatment of diabetes.

\subsection{Antifeedent activity}

Growth inhibitory activity and deterrency of Melia dubia extracts to Spodoptera litura and Helicoverpa armigera was investigated by Koul et al. (2002). Artificial diet bioassays using neonate larvae of both $S$. litura and $H$. armigera indicated that dichloroethane (DCE) and methanol (Me) extracts of $M$. dubia inhibited growth in a dose dependent manner. DCE and Me-5II fractions also resulted in $50 \%$ deterrency at concentrations of 22.5 and $16.8 \mu \mathrm{g} \mathrm{cm}^{-2}$ against $S$. litura larvae in a leaf disc-choice test. The DCE-5 fraction was found to be more toxic to larvae ( $\mathrm{LC}_{50}$ of $0.65 \%$ ) than the Me-5II ( LC $_{50}$ of $0.8 \%$ ), $72 \mathrm{hr}$ after topical application. Both fractions lack contact toxicity, but the deterrent effect persisted for at least $60 \mathrm{hr}$ under laboratory conditions. Chanthuru et al. (2014) evaluated mosquito larvicidal activity of ethyl acetate extract of leaves and root of Melia dubia and found that exposure of the larvae to these extracts for 12 hours led to 98 and $96 \%$ mortality, respectively. The results obtained from these studies shows that this plant material exhibited significant activity and could be considered as potent natural larvicidal agent.

\subsection{Biopesticidal activity}

Importantly, numerous compounds with pesticidal potency are present in different parts of $M$. dubia. Accordingly, many extracts of various parts of this plant show pesticidal properties. Refined bark consists $60-70 \%$ of toosandanin that can be used to control Helicoverpa armigera (Koul et al., 2002) and this compound is a strong antifeedant and growth inhibitor against Pierisrapae larvae (Shin-Foon, 1989). Limonoids from Meliaceae have the potential to control a variety of insect pests effectively without harming the environment (Carpinella et al., 2002). Many different extracts of $M$. dubia have ovicides (Malarvannan et al., 2009), larvicides (Karthikeyan et al., 2014), growth inhibitors, antifeedants, stomach poisons and cause moulting disorders and morphological defects in a number of pests (Bhuiyan et al., 2001). Kulawardhana et al. (2018) investigated the pest controlling potential of two Melia dubia leaf extracts, namely aqueous extract (T1) and aqueous formulation prepared using the methanol extract (T2) to control pests such as thrips, mealy bugs, scale insects and caterpillars. The methanol extract of $M$. dubia leaves can be used much more effectively than the aqueous extract to control thrips, mealy bugs and caterpillars. The aqueous formulation, which was prepared using the methanol extract of $M$. dubia leaves helps to prevent the damages caused by caterpillars in the crop cultivations to a great extent. Therefore, the yield can be secured as it prevents the reduction of the leaf area through reducing the number of caterpillars. M. dubia aqueous formulation applied to cabbage plants gave a significantly higher yield compared to the control.

\section{Conclusion}

Due to multiple uses in plywood, pulp wood and timber industry along with its fast growth and adaptability to varied agro-climatic conditions of the country, Melia dubia is also known as the money spinning tree of short rotation. The commercial cultivation of this indigenous tree is being preferred under different agroforestry systems at a large scale as allelopathy has not been reported in this species. The research work exploring medicinal properties of different plant parts of $M$. dubia have shown its potential scope for commercial use in medicinal plant industry in addition to timber industry. There is also need to make farmers aware about the scope and technique of cultivation of this multipurpose tree along with supply of good quality planting material.

\section{References}

Ahmad, M.F., Ahmed, M.A., Thayyil, H., Zameeruddin, K., Ibrahim, M., 2008. Antioxidative activity of Melia azadirach Linn leaf extract. Iranian Journal of Pharmacology and Therapeutics 7, 31-34. 
Ahmad, M.F., Rao, A.S., Ahemad, S.R., Ibrahim, M., 2012. Phytochemical studies and antioxidant activity of Melia azadirach Linn leaves by DPPH scavenging assay. International Journal of Pharmaceutical Applications 3, 271-276.

Anusuya, N., Anusuya, S., Manian, R., Siddhuraju, P. Manian, S., 2011. Antioxidant and free radical scavenging activity of certain dietary and medicinal plant extracts. Food 3, 47-52.

Bhuiyan, M.K.R., Hassan, E., Isman, M.B., 2001. Growth inhibitory and lethal effects of some botanical insecticides and potential synergy by dillapiol in Spodopteralitura (Fab.) (Lepidoptera: Noctuidae). Z Pflanzenk 108, 82-88.

Carpinella, C., Ferrayoli C., Valladares, G., Defago, M., Palacios, S., 2002. Potent limonoid insect antifeedant from Melia azadirach. Bioscience Biotechnology Biochemistry 66, 1731-1736.

Chanthuru, A., Prabhu, M.M., Aysha, O.S. Karthik, R., 2014. Evaluation of leaf and root extracts of Melia dubia L. against larvae of Culex quinquefasciatus and five important human pathogens. Biosciences Biotechnology Research Asia 11, 207-210.

Charde, R.M., Dhongade, H.J., Charde, M.S., Kasture, A.V., 2010. Evaluation of antioxidant, wound healing and antiinflammatory activity of ethanolic extract of leaves of Ficus religiosa. International Journal of Pharma Sciences and Research 19, 73-82.

Gamble, S.J., 1992. A manual of Indian timbers: an account of the growth, distribution, and uses of the trees and shrubs of India and Ceylon, with descriptions of their wood-structure. S. Low, Marston \& Company Limited, 145.

Gregory, P.J., Ingram, J.S.I., Andersson, R., Betts, R.A., Brovkin, V., Chase, T.N., 2002. Environmental consequences of alternative practices for intensifying crop production, Agriculture, Ecosystems and Environment 88, 279-290.

Husseiny, S.M., Salah, T.A., Anter, H.A., 2015. Biosynthesis of size controlled silver nanoparticles by Fusarium oxysporum, their antibacterial and antitumor activities. Beni-Suef University Journal of Basic and Applied Sciences 4, 225-231.

Kalia, A.N., 2018. Role of medicinal plants in national economy. Text book of Industrial Pharmacogonosy. CBS Publishers and Distributors Pvt. Ltd, New Delhi, 1-7.

Karthikeyan, J., Kamalanathan, M.N., George, T., Elangovan, V., 2014. Larvicidal and antibacterial efficacy of green synthesized silver nanoparticles using Melia dubia. International Journal of Pharmacy and Pharmaceutical Sciences 6, 395- 399.

Karthiravan, V., Ravi, S., Kumar, A.S., 2014. Synthesis of silver nanoparticles from Melia dubia leaf extract and their in vitro anticancer activity. Spectrochimica Acta Part A: Molecular and Biomolecular Spectroscopy 130, 116-121.

Khan, A.V., Khan, A.A., Shukla, I., 2008. In vitro antibacterial potential of Melia azedarach crude leaf extracts against some human pathogenic bacterial strains. Ethnobotanical Leaflets12, 439-445.

Koul, O., Jain, M.P., Sharma, V.K., 2002. Growth inhibitory and antifeedant activity of extracts from Melia dubia to Spodoptera litura and Helicoverpa armigera larvae. Indian Journal of Experimental Biology 38, 63-68.

Kulawardhana, T.D.D., Debarawatta, R.D.N., Pamunuwa, G., 2018. Biopesticidal Activity of Lunumidella (Melia dubia) Leaf Extract. Journal of Food and Agriculture 11, 37-48.

Kumar, H.K., Chauha, J.B., 2019. Assessment of anti-arthritic, anti-inflammatory and antioxidant activity of Melia dubia. Journal of Pharmacognosy and Phytochemistry 8, 2579-2582.

Makheswari, M.U., Sudarsanam, D., 2012. Database on antidiabetic indigenous plants of Tamil Nadu, India. International Journal of Pharma Sciences and Research 3, 287-293.

Malarvannan, S., Giridharan, R., Sekar, S., Prabavathy, V.R., Sudha, N., 2009. Ovicidal activity of crude extracts of few traditional plants against Helicoverpa armigera (Hubner) (Noctuidae: Lepidoptera). Journal of Biopesticides 2, 64-71.

Malarvannan, S., Lavanya, M., Prabavathy, V.R., Nair, S., 2009. Antimicrobial properties of Cipadessa baccifera and Melia dubia against human pathogens. Journal of Tropical Medicinal Plants 10, 135-143.

Mamun-or-Rashid, A.N.M., Hossain, M.S., Hassan, N., Dash, B.K., Sapon, M.A, Sen, M.K., 2014. A review on medicinal plants with antidiabetic activity. Journal of Pharmacognosy and Phytochemistry 3, 149-159.

Nagalakshmi, M.A.H., Thangadurai, D., Pullaiah, T., 2003. In vitro antimicrobial efficacy of leaf essential oils of Chukrasia tabularis Adr. Juss. and Melia dubiaPhytotherapy Research: An International Journal Devoted to Pharmacological and Toxicological Evaluation of Natural Product Derivatives 17, 414-416.

Netala, V.R., Kotakadi, V.S., Ghosh, S.B., Bobbu, P., Nagam, V., Sharma, K.K., Tartte, V., 2014. Biofabrication of silver nanoparticles using aqueous leaf extract of Melia dubia, characterization and antifungal activity. International Journal of Pharma Sciences 6, 298-300.

Nojima, H., Kimura, I, Chen, F.J., Sugihara, Y., Haruno, M., Kato, A., 1998. Antihyperglycemic effects of $\mathrm{N}$-containing sugars from Xanthocercis zambesiaca, Morus bombycis, Aglaonema treubii, and Castanospermum australe in streptozotocin-diabetic mice. Journal of Natural Products 61, 397-400.

Parthiban, K.T., Bharathi, A.K., Seenivasan, R., Kamala, K., Rao, M.G., 2009. Integrating Melia dubia in Agroforestry farms as an alternate pulpwood species. Asia-Pacific Agroforestry Newsletter 34, 3-4.

Parthiban, K.T., Seenivasan, R., Vennila, S., Anbu, P.V., Kumar, P., Saravanan, V., Kanna, S.U., Rajendran, P., 
Subbulakshmi, V., Durairasu, P., 2011. Designing and augmenting pulpwood supply chain through contract tree farming. Indian Journal of Ecology 38, 41-47.

Saber, M.M., Mirtajani, S.B., Karimzadeh, K., 2018. Green synthesis of silver nanoparticles using Trapa natans extract and their anticancer activity against A431 human skin cancer cells. Journal of Drug Delivery Science and Technology 47, 375-379.

Saravanan, V., Partiban, K.T., Thiruneraiselvan,S., Kumar, P., Vennila, S., Kanna, S.U., 2014. Comparative study of wood physical and mechanical properties of Melia dubia with Tectona grandis at different age gradation. Research Journal of Research Sciences 3, 256-263.

Schwab, U., Louheranta, A., Torronen, A., Uusitupa, M., 2006. Impact of sugar beet pectin and polydextrose on fasting and postprandial glycemia and fasting concentrations of serum total and lipoprotein lipids in middle-aged subjects with abnormal glucose metabolism. European Journal of Clinical Nutrition 60, 1073-1080.

Shah, S.N., Wani, T.A., Ram, B., Koul, M., Awasthi, P., Rajput, D.S., Reddy, G.R., 2016. An efficient protocol for in vitro organogenesis and antioxidant studies in Melia dubia Cav. African Journal of Biotechnology 15, 768-75.

Shin-Foon, C., 1989. Plants as a source of insect growth regulators for crop protection. Journal of Applied
Entomology 107, 185-192.

South, D.B., 1999. How can we feign sustainability with an increasing population?. New For 17, 193-212.

Srivastava, M.B., 2005. Timber industries and non-timberforest products. CBS Publication, New Delhi, 518.

Susheela, T., Balaravi, P., Theophilus, J., Reddy, T.N., Reddy, P.U.M., 2008. Evaluation of hypoglycaemic and antidiabetic effect of Melia dubia CAV fruits in mice. Current Science 94, 1191-1195.

Thakur, I.K., Chauhan, K.C., 2008. Improvement of Morus alba variation, estimates of genetics parameters and correlation in different accession. Indian Journal of Forestry 31, 423-428.

Valentina, P., Ilango, K., Kiruthiga, B., Parimala, M.J., 2013. Preliminary phytochemical analysis and biological screening of extracts of leaves of Melia dubia Cav. International Journal of Research in Ayurveda and Pharmacy 4, 417-419.

Yadav, D., Sahoo, G., Wani, A.M., 2019.Growth performance and variability studies in different half sib families of Melia dubia under green house condition. Journal of Pharmacognosy and Phytochemistry 8, 1008-1011. 